\title{
Lines out across the Gap: An Interview with Pam Durban
}

\section{Jan Nordby Gretlund}

Odense, Denmark

Part I: Beaufort, South Carolina, January 23, 2004

Gretlund The father figures are a powerful presence in both the stories of All Set About with Fever Trees and in The Laughing Place, your first novel, even to the extent that he dwarfs out the role of the mother figures. Many writers will not even talk about their parents, but you write about yours all the time.

Durban It is one of the central dynamics of my life. The place my father occupied in my life was central, as you can tell from my essay called "The Old King." I am thinking of it as a part of a book, for which I have three essays done. The name of another essay is "Veterans" and it is about the Christmas immediately after my mother's death, when I tried to go and make Christmas for my father. And both of us failed at it. We tried, but we ended up watching all ten episodes of "Band of Brothers." It follows a company of parachutists who were dropped into France on Dday and then fought all the way through.

Gretlund And this had your father's interest?

Durban He was interested in everything to do with the war. He was in the Pacific as a combat infantry commander, so he was right there in the thick of it. "The Old King" is about his last two years. It was amazing how much he still had inside of him, you couldn't fight him. 
And you realized what a commander he must have been. He would have fought us every step of the way, if we'd tried to put him into a home. And he would have won, he had that in him. - He called me his 'second-in-command.'

Gretlund But in your fiction you are not writing of the family in any idealized sense. Mostly it is father, mother, and daughter, as in The Laughing Place. There was a brother in that novel, why does he disappear out of the narrative?

Durban I didn't think I could carry him through. It may have been a mistake, but the book won. It took me a long time to write it and I just had to give up on him. I cut 150 pages out of that manuscript. It is long, but I did cut it. It took me seven years to write. The first time through I had 400 pages of language, and not much of a story. So the rest of the time was spent finding the story and strengthening the story-line that runs through the book.

I will tell you something funny. My editor at the time, after I had turned in the manuscript at one time, came down. And her idea for what I needed to do in the book was to make Melanie, the father's illegitimate child with his secretary. So 'perfect Mel' would be marrying her halfbrother. My editor wanted it to be revealed at the wedding, so there would be this big dramatic scene. - It was so depressing to me that this was what they wanted that I could not work on it for several weeks after that.

Gretlund Just looking at the titles of your books makes it obvious that place is important for you.

Durban Place is really important and I see that even more now after dismantling my parents' house, the house where I grew up. I took my father's desk, the most beautiful bird's eye maple desk, to my house and put it in one of the rooms. Of course, it is not the same thing; it doesn't have the same presence there. What matters are things in their places. The place of things is as important as the things themselves, so it is a whole. Memory is built on the unified whole: the recollection of this object, this person in this room, and in this particular light. So 
place is to me the center of all of that. You come back to it again and again, it is the place that's always there; that's what's important to me about it.

Gretlund Does place matter wherever you happen to be?

Durban Yes, in fact the novel that I have in my mind now, I've started pieces of it, begins in Ohio and ends up in El Paso, Texas. So the journey between these two places is important, but El Paso is the important place. - That's where my husband is from. - I think it is having grown up the way I did and where I did. Maybe it is Southern that the place is so important. It is the place you came from, it is the place, if you are lucky, where people like you came from for generations. It is a certainty, in a way, and that is why it is so devastating when it changes or falls apart. As it does with the flooding of the valley in Ron Rash's One Foot in Eden, which we talked about this morning.

The very same flooding is in The Laughing Place. I worked in Seneca, South Carolina, on the newspaper there when that lake was being built and that is where that image comes from. Lake Jocassee is what the lake is actually called.

Gretlund I thought the senator behind the creation of that lake sounded a lot like old Strom Thurmond.

Durban Yes, he is Old Strom.

Gretlund There is a lot of poetry in your description of the landscape. Have you written any poems?

Durban I started out as a poet. But I only published in little magazines that don't even exist anymore. But when I went to Iowa to graduate school, I was accepted in both the fiction and the poetry workshops. I decided early on that I needed to focus on one and would rather write fiction.

Gretlund But as 'a failed poet' you are now qualified to write great fiction. 
Durban Exactly! [laughing].

Gretlund In the information you gave me about yourself for the South Carolina Encyclopedia, you mention publishing interviews with textile workers [in Cabbagetown Families, Cabbagetown Food, 1976]. Do you have a strong social concern?

Durban I wonder what drove me to it. - My mother's family were textile mill people, that's the more personal concern. But it was what $I$ did, I was working at a little social services organization at an old textile mill village in the middle of downtown Atlanta, a place called Cabbagetown. I had a job there, just working for a non-profit organization. My title was communications coordinator and basically I did this book. I did those interviews to keep from going nuts, because there was nothing much to do really. It was a very, very poor place. You know how those non-profit units make up all these things you're supposed to be doing; I was supposed to be doing brochures about the organization. Instead I started working with the kids. And I was taking the kids of the neighborhood with me to interview these older women. Some of the kids liked it a lot and were really into it. These were visits with the oldest women in the community, it was a very close-knit community. The oldest women were their grandmothers, or the kids had known them, or had made fun of them all their lives. That's what made it good for them to hear the stories.

Gretlund Did the old women tell you their life stories?

Durban It was pretty amazing. - I am still proud of that book. It took about a year, and I went back, over and over again, to talk with them. I would just start it and we would go off on something, and I'd listen to that and figure out something else and go back. I pieced it all together so that there was a narrative. Then I went back and read it to them, if they wanted me to; some of them couldn't read. - There's some pretty bitter stuff in there.

Gretlund Had they ruined their health working in the mill, like Gree's father in The Laughing Place [who got emphysema from breathing cotton dust for forty years]? 
Durban If I had stayed there my next project was to talk with the oldest men about the textile industry. Even though they would not talk about the strike, in 1930 , I think it was.

Gretlund It sounds almost as if you, unaware, were collecting material for future fiction.

Durban I was. That's actually where I began writing. In fact my first 'big' publication, the story "This Heat," was based on something from that time and that place. Stanley Lindberg published it in the Georgia Review [in 1982]. The Cabbagetown book is out of print, but a theater group in Atlanta still performs a play based on it, called Cabbagetown: Three Women.

Gretlund Did you work as a journalist in Atlanta?

Durban I was one of the founding editors of a literary magazine called Five Points. I was the fiction editor. But before I had that job, I worked as a journalist for The Great Speckled Bird, one of the great alternative newspapers of the time. Then some friends of mine started their own newspaper The Atlanta Gazette and I went to work there [1974-75].

Gretlund Do you feel that the training in the newspaper world has helped you in your career as fiction writer?

Durban Yes it has. - Although, it is interesting now, that I always know if I have somebody in one of my classes majoring in journalism. They have the hardest time in the fiction class because of the way they are taught. They have all these really mechanical models. I didn't have my training in journalism, I just went to work on a newspaper in Seneca. But now it is a school and you are taught exactly how to write and think. - But I do believe the work has helped me. I learned how to observe, and how to think of the questions to ask, even of myself, about a situation.

Gretlund But you did not have a Kansas City Star "style-sheet" to guide you? 
Durban No I didn't. But I do feel my style is getting simpler, more direct, I like that.

Gretlund In your fiction there is an emphasis on the lingcring presence of the past. Is that your Southerness coming out?

Durban It probably is. But it is also a function of having lived. I'm sure that for people in other parts of the country, who have grown up in a place where the family has lived for a long time, the past is always still there around you, it's like you're living the past. - Do you know the essay I have on the subject in Eve Shelnutt's book The Confidence Woman [1991], called "Layers"? - I wonder what's peculiarly Southern about the past in the present.

Gretlund It is not that the dialogue between past and present is not recognized elsewhere, but Southern writers pick it out and talk about it. They deal not only in 'time is' but also in 'time was,' as you also do in So Far Back. In New York they may think more about the present. During the Reconstruction occupation the present may have seemed shabby and the past may well have looked better to defeated Southerners.

Durban Isn't it typical of people everywhere to think of the past as a golden time?

Gretlund Not necessarily, in many places people can't think of the past as anything but terrible, of how depressing it was, how dirty and poor, how early people died, and how much better it is today. And there is certainly no idea from the past that is worth much today. As Mark Twain said: "Old Europe is a dust pile."

Durban Maybe it is just a function of that Southern mythologizing, that denial, that attempt to make the past into something better than it was. I have an essay that I sketched-in years ago about sentimentality and Southern memory. It's like the perfumed handkerchief held to your face as you walked the smelly streets of Charleston. Maybe it is a function of denial to glorify the past. 
Gretlund In your fiction you obviously warn against the falsification of the past, what is it we do that is falsifying ? Aren't we just celebrating our ancestors?

Durban We falsify by only allowing so little of it in. Of course it can't be changed; it can't be healed by apologies or anything else. The only thing that can happen now is that you can look at it and acknowledge that you see it more clearly. And the evidence is there, if you will look at it, the imbalance of it, and the evidence of the injustice of it. But we only see one side of the story as long as we only have that one side of it and don't want the reality of the other. We only tell the 'white' side of it.

Gretlund Don't we tell the whole story in museums and history books nowadays?

Durban Now they do more, but not in Charleston. Part of my research for So Far Back was to go on every one of those house tours. How is it that they never once mention slaves? It was like those houses grew up out of the ground like flowers and only white people live there.

Gretlund In Europe, perhaps also in the US, many people have the impression that contemporary black Southerners are really depressed about their slave ancestors. Actually, the black people I have met are very proud of what their ancestors contributed to Old South architecture, the craftsmanship that made it all possible. I think that should be mentioned.

Durban Do you know what the beginning of that awakening was for me? Friends I've had from the North think I am being disingenuous when I say "we didn't think about that when we were growing up." But there was nothing that would encourage you, permit you, or lead you to think about that. - I was driving through the blue grass part of Kentucky, up near Paris, Kentucky where the thoroughbred farms are. There are miles and miles of intricate stonewalls that run along there. We were with some friends from Louisville, and our friend said "there's a guy in town who 
has a business renovating and restoring these walls, and he is a descendent of one of the slaves who built the walls." And it was like it hit me, it was a bolt of lightening!

So now I realize that all these things we claim as our own, all these walls in Charleston, the beautiful ironwork, the houses, the gates, the bricks of the streets, and all of that, which are symbols for us of our way of life once, do not belong to us at all.

Gretlund And the Charleston baby gown in So Far Back?

Durban And the baby gown, too.

Gretlund Did the gown really exist?

Durban It did, yes. I saw it on that pedestal during one visit. I went back later and it was gone. And I made an appointment with the textile archivist, who looked at all the garments they had, and they couldn't find it! I don't know if it were in a traveling exhibit, or what happened to the gown, but it was there at one time.

Gretlund Josephine Humphreys talked to me about the racial situation in Charleston and mentioned that in some ways the racial situation is better there today than it was in 1989 .

Durban I can't say. I don't live in Charleston. It is very different where I live now, because it is in the upper South [Chapel Hill, NC]. The African Americans that live there don't have the past that they have in the Lowcountry. That past is particular to the Lowcountry.

Gretlund Down her in Beaufort County, SC, black people are proud of their Gullah dialect, their music, and their cuisine. You don't feel that you meet with people that have been deprived of their identity.

Durban No, you don't. I think their identity has remained intact in time and place; perhaps because they were isolated on the islands. They know who they are. They know their origin, history, and culture. 
Gretlund The Lowcountry would not be what it is without the 400 years of black and white cohabitation.

Durban We go shrimping every year down on Jekyll Island with friends of ours from Ohio. One time on a beach where everybody goes to shrimp, there were two men, who had this wonderful elaborate set-up for their shrimping, one of the guys was black and one was white; I think they were military friends. I was just talking with them about shrimping and when I was done, my friend from Ohio said "that never happens in Ohio!"

Gretlund Don't you think that if the Ohioans are around long enough, they will imitate even that?

Durban Yeah, I think so. Yeah [laughing], I do.

Gretlund Barry Hannah said "drop the bomb on Ohio." And Walker Percy claimed that if you found yourself in Disney World, wondering why you were there, you would be standing next to people from Ohio. And Josephine Humphreys write funny things about people from Ohio looking for the shortest way to the sea.

Durban She does, I've noticed that. Ohio comes in for that kind of ridicule.

Gretlund I wonder if it is really a deep-seated historical prejudice. There seems to be an overload of monuments to dead Ohioans in the southern Civil War battlefield parks.

Durban I guess that's right. But I don't even know how much the War matters anymore. I guess it means a lot to some people and maybe it lingers in the stories people tell.

Gretlund Talking about monuments to the dead, it struck me that throughout your fiction, you are preoccupied with aging! Most people do not like to think of the spotting and clodding, but you seem determined to constantly face the fact that we are falling apart. 
Durban That seems to me to be one of the central facts of life, isn't it? Why do I write about it? I guess that is what I see in people. I fear it. But I would say that I'm more preoccupied with death or dying than with the process that leads you there.

Gretlund I'm not thinking of just the physical disintegration, but also the fact that we disappear even as a memory.

Durban What I realize now, having just lost my parents, and seeing my son grow up, is that people are not going to remember you. My son will probably pass on things to his children about us, but how much he will pass on about his grandparents I don't know, and so they will be forgotten. When I'm gone, and when my brother and sister are gone, they'll be forgotten.

Gretlund And so, according to Katherine Anne Porter, their lives might never have been, if they were not recorded.

Durban Right. And there are millions of people to whom that happens. My husband is a photographer and he likes to ask antique stores if they have old photographs. And he comes upon whole collections of photos of people nobody knows who are any longer. They have clearly been discarded by someone. And those people are gone from the earth.

Gretlund In Europe we tend to think of the South as a place where names, births, and deaths of ancestors are remembered. But maybe this is no longer true?

Durban We just opened my father's safety-deposit box. And in it were all these documents, some from my mother, where her mother was applying for membership in the United Daughters of the Confederacy. There was the whole account of who Joseph Palmer was, where he was born, and what qualified my grandmother to be taken into the UDC. Maybe it is a generational thing, for all those people knew their people a long way back. 
Gretlund But you didn't know about this old application before the safe was opened?

Durban I knew vaguely, but did not remember his names. I couldn't tell you where he is buried. So maybe it is passing now. - But you would think that in old Europe people would celebrate the memory of ancestors; but maybe the detailed memory is a function of not being old?

Gretlund Europeans often see the attention paid to your Civil War, as being out of proportion and as a result of your brief history.

Durban And we are young enough to think that it is important to remember all of that and to trace back your family history. Look at the obsession that people in this country have with finding out if their family came over on the Mayflower.

Gretlund That $i$ f funny. I find, by the way, that you can be a most humorous writer, but that you do not allow yourself to be so very often. Mostly your fiction is serious and fully focused.

Durban This was one of the things I intended to get across in "The Old King," by saying 'you can laugh at this.' It is a serious topic, but it did strike me as funny, a lot of it, and I thought I got that across. I was really pleased with that essay in part because of that. I mean I was able not to write it as this mournfully sad piece.

Gretlund You did that with non-fiction, which is difficult. Whereas you would think it would be easier to sport with 'serious' topics in fiction. But you haven't done much with rollicking humor in your fiction.

Durban Yeah. And it is funny because I think in person people think of me as having a great sense of humor. Maybe as I get more comfortable with myself as a writer, and more confident, I'm going to do it.

Gretlund But not everybody wants to be Mark Twain. 
Durban No. True, and I don't. But I still appreciate humor. You know who does that really well is Tobias Wolff. He writes very droll humor.

Gretlund Some writers, like Clyde Edgerton, will sell their soul for a good anecdote. Also when it was not exactly what the reader was hoping for.

Durban I know. See I think it can go too far in that direction, too. And that's my worry.

Gretlund But Faulkner was very funny sometimes and Miss Welty.

Durban And Flannery O'Connor!

Gretlund Oh, above all! In my irreligious country readers do not pay much attention to her religious aim, but O'Connor was funny and is wellknown there.

Durban Just her descriptions, and her timing!

Gretlund As a point of departure for your narrative, you often use a diary or old family letters, as if you try to bring out the present by constantly relating it to the past. Is this a favorite strategy?

Durban It must be. In terms of the essays I am writing now, there's one thing I am thinking forward to: in my parents' attic I found a suitcase with their letters back and forth during WWII. And I'm shaping in my mind another essay for this collection about those letters and their lives together.

Gretlund Why do you turn that material into non-fiction? Do you feel uncomfortable exploiting it through fiction?

Durban No, I did that before with my father's actual diary, a whole narrative, that he kept throughout the war ["Notes Toward an Understanding of My Father's Novel," 1983]. Most of it is tedious: the first day we are on the ship; the second day we are on the ship ... but I 
can edit it and make it into a real narrative. There are some really amazing parts to it: the first day in combat; the first dead man he saw; the first ....

Gretlund I've noticed that you stress other senses than just sight, especially the olfactory sense. It is obvious, of course, in your description of the Charleston of 1837 in So Far Back.

Durban It struck me one day, when I was walking around down there, doing research for the novel. Sometimes you'll just catch a whiff. It is either the paper-mill and the wind blowing the wrong way or the pulp that smells; or just the smells that come up from those grates in the sidewalks. I just catch a whiff and I realize this city really stinks. And in antebellum time it really had to, with the damp rotting wood and their privies.

The story I'm finishing now is about a child, an adopted child. I was reading back over it just the other day and a lot of it has to do with smell, the smell of his mother, the smell of his sister, and of things he remembers.

Gretlund You do not devote much space to old time religion. If religion is brought in, it is to be ridiculed, as in the section of the mother getting saved in The Laughing Place, which reads as a hilarious short story.

Durban Yes. I don't know why, exactly. I think that, above all, is an adopted attitude. I was brought up Catholic and it is very serious to me. I consider lots of things in organized religion really destructive, but I don't consider spirituality a joke, at all. It is some inner sense of a larger meaning, within what one's life exists. I am not cynical about religion. Even now I would like to be able to go to church, because it is important to me. But I want to sit there with one of these little cards that a person who is deaf or blind will come and hand to you in a store. I want to be able to hand that to the people who want you to join and to bring a casserole, to hand them a card saying: 'I am a contemplative, may I please come to your church to take communion and not have to bring a casserole?' [laughing]. Religion is very serious to me, but I don't know how to write about it. 
When my father was dying, it meant a lot to all of us, especially that the priest was able to come, and it certainly meant a lot to my father. $\mathrm{He}$ had been a Catholic all his life; it meant a lot to him for the priest to come to hear his confession and to give him communion.

My mother was a Presbyterian. So when they got married, which was a long while back, she literally, she often told, had to sign us away. She relinquished any kind of influence over our religious upbringing. That was the law of the Church for a Catholic to marry a non-Catholic. They had to sign a paper saying that their children would be raised Catholic and not Protestant. That sounds medieval [laughing].

Gretlund In your fiction there are women whose identity resides in the dishes they make. So if you hear the name 'Catherine Henderson,' you will expect 'Squash Casserole.' Is it still true that Southern women make their identity in this way?

Durban I don't know, but food is a major theme in the South. When my mother was dying, in the morning word would go out that she liked custard, or that she liked that fruit salad from Publix, and by afternoon there would be ten custards there, or ten fruit salads. All her friends had brought them. It was because of the connections she had made with people over time, those all came back to her then, people really took care of her. - Her life with my father was tough, he was a difficult man, impossible, you can tell. But my mother had friends, she played bridge all the time, she was a great bridge player and that was her life. - My father had not made such connections. Men don't do that and he was very lonely. I took care of him for the last two years of his life. He didn't have much in terms of other people.

Gretlund I have always been interested in Southern stoicism. If I see it in your fiction, it is in your women characters. Are Southern women 'stoics.'

Durban Yes. Definitely, that is one of the archetypes: optimistic, fierce, and determined. They do what is needed, always have, and always will. My mother was that way when she was dying. I had never quite seen that part of her before. She said: "I have liver cancer and my doctor and I 
have decided we are not going to do anything. You know that I had a good life. It is in God's hands." Even if she had not had religion, she would have been strong. And everybody who took care of her said that. I have never seen anybody as brave as she was.

Gretlund In your first novel Melody Givens is given beauty with grace and confidence, whereas Annie Vess has to struggle to gain hers. Does so much still depend on beauty criteria in the South?

Durban I think so. If you look around you [in Beaufort County] there are women around here who are sixty and still look thirty. I don't know why, but it is true that that remains acute.

Gretlund In Europe we also celebrate beauty, but in itself it doesn't give you a standing in society. Melody seems to live off her beauty, and being 'Miss Sun Fun,' 'Miss Vaucluse County,' and, my favorite, 'Miss Rural Electrification.'

Durban [laughing] My cousin was Miss South Carolina one year, and she had some trouble with the description of Mel. - 'Miss Rural Electrification,' see that's funny, so I have a sense of humor!

Gretlund There are romantic scenes in your fiction, men and women are attracted to each other, and presumably have sex. Do you feel it would cheapen your work if you were to describe sexual encounters?

Durban With some of my classes, it's funny, I used to have a contest, I would say: 'write the best sex scene.' And they try to write one and it is really hard to do, it is almost impossible. You either go to a sort of romantic lushness or to some kind of clinical description, which is not good either. I just never found a way to do it.

Gretlund But you describe the animal attraction of some men, such as Canady in The Laughing Place, very well.

Durban That is again what you take from your life and other places and bring into fiction. When I met my now husband and we had started 
dating, we went to his cousin's wedding, and she married somebody like that. He was one of the breathtakingly handsome men and he knew. He was going around at this recaption talking to women and holding their hand. But he was really taking their pulse to see what he was doing to them. It was pretty terrible and he actually turned out to be ...

Gretlund I kept expecting Canady, the handsome man, to get a hard time. But he never quite does.

Durban But he does! When he shows up to get his baby, he doesn't even know that the baby needs a sweater! That's another funny scene.

Gretlund What we have been talking about today has really been about reality and fiction. And I am tempted to conclude that there isn't much difference. Everything you write has at least a basis in reality.

Durban Yes, those are the things that draw me, I don't know why. Those are the things I see; but it is invented around. And as Chekhov always said: "I can't write about what I don't know!"

Gretlund But you do more than report reality, in the way you use your art existentially to overcome the alienation you write about. You use the power of words not only to soothe, but to try to bridge the gap between you and reality. In your fiction your characters share obvious feelings of being alienated; but through art they try to overcome their problems.

Durban Yes, that's true, and they try to make connections where they can. They throw these lines out across that emptiness, that loneliness, or that alienation.

End of Part I.

Part II was taped on September 21 and 23, 2005, in Odense, Denmark. It is focused on the novel So Far Back and racial issues. 